\title{
INDEX FOR VOLUME 11
}

Journal of Direct, Data and Digital Marketing Practice (2010) 11, 363.

doi:10.1057/dddmp.2010.7

\section{Papers}

Media synergy comes of age

Data quality is everyone's business

Automated marketing and 'customer compliance' Search marketing ... promoting the conversation

What happened to strategic segmentation?

A multi-industry, longitudinal analysis of the email marketing habits of the largest US franchise chains

Web content management: CMS for competitive advantage

The disloyalty ladder -Two rungs further down

Do happy staff make for happy customers and profitable companies?

Minimum effective frequency for interactive TV ads

Direct, database and digital marketing practice in the government sector: black hole or parallel universe?

\section{Opinion Pieces}

DDDMP - My ten year top ten

DMA shapes up for future challenges

What innovation programmes can learn from sales

\section{Case Studies}

Virgin Media

Waterstones

VisitScotland

Swinton Insurance

Citi International Personal Bank

\section{New Technology Briefing}

Online customers, digital marketing

Linking spatial data from the Web

Why marketing needs speech analytics

\section{Book Reviews}

Marketing Sherpa Toolkit: How to Viral Market

Powers of Persuasion: The Inside Story of

British Advertising by Winston Fletcher

How Public Service Advertising Works by Judie Lannon

Future Files: The 5 trends that will shape the next 50 years by Richard Watson

\section{Author \\ Schultz, Block and Raman}

Breur

Kasabov and Warlow Grehan and Pettijohn Jenkinson

Abrahams, Choudhary and Deane

Short

Ozimek

Stewart

Bellman, Schweda and Varan

Apicella and Streatfeild

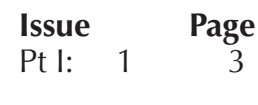

Pt 2: $2 \quad 88$

Pt I: 120

Pt 2: 2114

2

3

3

Chaffey

Combemale

Bodell

Boothby

Boothby

Boothby

Boothby

Boothby

Peterson Volkman, Koch,

Gröne and $V_{0}$

Becker and Furness

Fluss

Wilson and Pettijohn

Fairlie

Morris

Fairlie

262 